\title{
Dynamics in benthic community composition and influencing factors in an upwelling-exposed coral reef on the Pacific coast of Costa Rica
}

Ines Stuhldreier, Celeste Sánchez-Noguera, Florian Roth, Carlos Jiménez, Tim Rixen, Jorge Cortés, Christian Wild

Seasonal upwelling at the northern Pacific coast of Costa Rica offers the opportunity to investigate the effects of pronounced changes in key water parameters on fine-scale dynamics of local coral reef communities. This study monitored benthic community composition at Matapalo reef $\left(10.539^{\circ} \mathrm{N}, 85.766^{\circ} \mathrm{W}\right)$ by weekly observations of permanent benthic quadrats from April 2013 to April 2014. Monitoring was accompanied by surveys of herbivore abundance and biomass and measurements of water temperature and inorganic nutrient concentrations. Findings revealed that the reef-building corals Pocillopora spp. exhibited an exceptional rapid increase from 22 to $51 \%$ relative benthic cover. By contrast, turf algae cover decreased from 63 to $24 \%$, resulting in a corresponding increase in crustose coralline algae cover. The macroalga Caulerpa sertularioides covered up to 15 $\%$ of the reef in April 2013, disappeared after synchronized gamete release in May, and subsequently exhibited slow regrowth. Parallel monitoring of influencing factors suggest that $C$. sertularioides cover was mainly regulated by their reproductive cycle, while that of turf algae was likely controlled by high abundances of herbivores. Upwelling events in February and March 2014 decreased mean daily seawater temperatures by up to $7^{\circ} \mathrm{C}$ and increased nutrient concentrations up to 5- (phosphate) and 16-fold (nitrate) compared to mean values during the rest of the year. Changes in benthic community composition did not appear to correspond to the strong environmental changes, but rather shifted from turf algae to hard coral dominance over the entire year of observation. The exceptional high dynamic over the annual observation period encourages further research on the adaptation potential of coral reefs to environmental variability. 
1 Dynamics in benthic community composition and influencing factors in an upwelling-

2 exposed coral reef on the Pacific coast of Costa Rica

3

4 Ines Stuhldreier ${ }^{1,2, *}$, Celeste Sánchez-Noguera ${ }^{1,3}$, Florian Roth $^{1,2}$, Carlos Jiménez $^{3,4}$, Tim Rixen ${ }^{1}$,

5 Jorge Cortés ${ }^{3}$, Christian Wild ${ }^{1,2}$

6

$7 \quad{ }^{1}$ Leibniz Center for Tropical Marine Ecology (ZMT), 28359 Bremen, Germany

$8 \quad{ }^{2}$ Faculty of Biology and Chemistry (FB2), University of Bremen, 28359 Bremen, Germany

$9{ }^{3}$ Centro de Investigación en Ciencias del Mar y Limnología (CIMAR), Universidad de Costa

10 Rica, San Pedro, 11501-2060 San José, Costa Rica

$11{ }^{4}$ Energy, Environment and Water Research Center (EEWRC) of the Cyprus Institute (CyI), 1645

12 Nicosia, Cyprus

13

* Corresponding author: Ines Stuhldreier

Phone: +49-421-23800-102 
19 Abstract

20 Seasonal upwelling at the northern Pacific coast of Costa Rica offers the opportunity to

21 investigate the effects of pronounced changes in key water parameters on fine-scale dynamics of

22 local coral reef communities. This study monitored benthic community composition at Matapalo reef $\left(10.539^{\circ} \mathrm{N}, 85.766^{\circ} \mathrm{W}\right)$ by weekly observations of permanent benthic quadrats from April 2013 to April 2014. Monitoring was accompanied by surveys of herbivore abundance and biomass and measurements of water temperature and inorganic nutrient concentrations. Findings revealed that the reef-building corals Pocillopora spp. exhibited an exceptional rapid increase from 22 to $51 \%$ relative benthic cover. By contrast, turf algae cover decreased from 63 to $24 \%$, resulting in a corresponding increase in crustose coralline algae cover. The macroalga Caulerpa sertularioides covered up to $15 \%$ of the reef in April 2013, disappeared after synchronized gamete release in May, and subsequently exhibited slow regrowth. Parallel monitoring of influencing factors suggest that $C$. sertularioides cover was mainly regulated by their reproductive cycle, while that of turf algae was likely controlled by high abundances of herbivores. Upwelling events in February and March 2014 decreased mean daily seawater temperatures by up to $7^{\circ} \mathrm{C}$ and increased nutrient concentrations up to 5- (phosphate) and 16fold (nitrate) compared to mean values during the rest of the year. Changes in benthic community composition did not appear to correspond to the strong environmental changes, but rather shifted from turf algae to hard coral dominance over the entire year of observation. The exceptional high dynamic over the annual observation period encourages further research on the adaptation potential of coral reefs to environmental variability. 
41

42

43

44

45

46

47

\section{Introduction}

Coral reef benthic communities are controlled by abiotic and biotic drivers, such as waves, water depth, reef habitat, temperature, nutrients and herbivory (Littler \& Littler, 1984; Kleypas, McManus \& Meñez, 1999; Gove et al., 2015). Anthropogenic disturbances (e.g. herbivore removal or nutrient and sediment input) may affect these drivers and decouple biophysical relationships between environmental and biotic conditions (Williams et al., 2015). Long-term background physical conditions drive spatial patterns in benthic community composition (Done, 1992; Hughes et al., 2012). Although it is recognized that also low- and high-frequency variations in environmental conditions can alter coral reef benthic community composition and productivity (Leichter, Stewart \& Miller, 2003; Gove et al., 2015), it is not well known which parameters are most influential in driving benthic community composition on a fine temporal scale.

To understand the effects of variable environmental drivers on coral reef ecosystems it is useful to monitor ecosystems with a pronounced natural temporal variability in conditions, such as upwelling regions. Transport of subthermocline water to the surface (in the form of coastal upwelling, large amplitude internal waves (LAIW) and internal bores) acts to decrease sea water temperature and increase nutrient concentrations in reef waters on different temporal scales ranging from minutes to several days (Leichter \& Miller, 1999; Leichter, Deane \& Stokes, 2005; D’Croz \& O’Dea, 2007; Schmidt et al., 2012). Previous studies in areas exposed to upwelling or LAIW mainly focused on spatial differences in benthic communities comparing exposed versus sheltered sites (Glynn \& Stewart, 1973; Roder et al., 2011; Schmidt et al., 2012). Studies on temporal differences in benthic community composition in response to upwelling are scarce (but see Eidens et al., 2015). In general, observations on a high temporal scale are often lacking in 
64 coral reef ecology. By conducting weekly observations over an entire year of monitoring, the

65 present study aimed to advance the understanding of fine-scale dynamics in coral reef

66 community composition, particularly in response to seasonal upwelling conditions.

67 We selected the Gulf of Papagayo at the northern Pacific coast of Costa Rica to investigate the

68 question of how annual variability in environmental parameters affects coral reef communities. A topographic depression in the lowlands of southern Nicaragua and northern Costa Rica allows strong winds to blow across from the Caribbean during the northern hemisphere winter (McCreary, Lee \& Enfield, 1989; Amador et al., 2006; Willett, Leben \& Lavín, 2006). On the Pacific side, this leads to the displacement of superficial waters away from the coast, which causes the shallow thermocline to break the surface (Fiedler \& Talley, 2006). This seasonal upwelling can decrease mean seawater temperatures from around $28{ }^{\circ} \mathrm{C}$ between May November to $23{ }^{\circ} \mathrm{C}$ between December - April (Jiménez, 2001a; Alfaro et al., 2012). During pronounced upwelling events, water temperatures can drop by $8-9{ }^{\circ} \mathrm{C}$ (Alfaro \& Cortés, 2012). Low temperatures are accompanied by decreases in $\mathrm{pH}$ and oxygen concentration (Rixen, Jiménez \& Cortés, 2012) as well as peaks in inorganic nutrient concentrations, which seasonally promote the growth of fleshy macroalgae (Fernández-García et al., 2012; Cortés, SamperVillarreal \& Bernecker, 2014).

The present study monitored the temporal variation in a reef community exposed to moderate upwelling in a weekly resolution over one year. Observations of benthic community composition were accompanied by monitoring of herbivores (sea urchin abundance and fish biomass) and key water parameters (temperature and inorganic nutrient concentrations). The objectives of the study were to (1) observe the dynamics in benthic community composition over one year, (2) identify the influencing biological and (3) environmental factors and (4) develop an ecological 
87 perspective for local coral reefs. Important related key questions were: (i) which benthic groups benefit from seasonal changes in biotic and abiotic parameters? (ii) which parameter has the strongest effect on benthic community composition? and (iii) does the benthic community follow a seasonal cycle?

\section{Methods}

\subsection{Study site}

The study was conducted at Matapalo reef, located $12 \mathrm{~km}$ south of Culebra Bay in the Gulf of Papagayo at the northern Pacific coast of Costa Rica from April 2013 to April 2014 (Fig. 1a). The reef framework at Matapalo in 3-9 $\mathrm{m}$ water depth is built by branching corals of the genus Pocillopora and stretches $1.2 \mathrm{~km}$ from Punta Matapalito to the west end of Playa Matapalo (Fig. 1b). Field work was conducted under permits issued by the National System of Conservation Areas (SINAC) of Costa Rica (permit No: 019-2013-SINAC).

\subsection{Monitoring of benthic community composition}

Monitoring took place on a reef patch of around $600 \mathrm{~m}^{2}\left(10.539^{\circ} \mathrm{N}, 85.766^{\circ} \mathrm{W}\right), 500 \mathrm{~m}$ northwest of Playa Blanca (study site in Fig.1b). Quadrats of 50 x $50 \mathrm{~cm}(\mathrm{n}=5)$ were permanently marked with iron stakes and repeatedly observed for changes in benthic coverage every week. The location of permanent quadrats was chosen by placing a $50 \times 50 \mathrm{~cm}$ frame alternately left and right every $2 \mathrm{~m}$ along a transect line parallel to the coast in $5 \mathrm{~m}$ water depth. For observation, the PVC frame with a $5 \times 5 \mathrm{~cm}$ grid was placed over the stakes as a reference, and live coral, dead coral, crustose coralline algal (CCA), turf algal, macroalgal, sand, rubble and sessile benthic invertebrate cover on the substrate was quantified from directly above the grid using SCUBA. The weekly quantification was done on a relatively small area of the reef, but results 
110 were supported by monthly chain surveys along transects covering the whole reef patch.

111 Transects of $10 \mathrm{~m}$ length $(\mathrm{n}=5)$ were permanently marked with iron stakes parallel to the coast

112 in $5 \mathrm{~m}$ water depth in about $3 \mathrm{~m}$ distance to the permanent quadrats. A $10 \mathrm{~m}$ iron chain with 532

113 links was laid out over the reef substrate along each transect, and seafloor coverage was observed

114 under each link. Proportional seafloor cover was calculated by relating the average number of

115 links in each category to the total number of links, and rugosity was calculated by dividing the

116 horizontal distance covered by the chain (d) by its real length (1) (rugosity index: RI = 1-d/l).

\section{$117 \quad 2.3$ Monitoring of herbivores}

118 Surveys of sea urchin and fish abundances were conducted monthly between 9:00 and 14:00 on

119 all five permanent transects using SCUBA. Sea urchins of the species Diadema mexicanum and

120 Eucidaris thourasii were counted in $1 \mathrm{~m}$ belts on both sides of the transect lines (total survey

121 area $=100 \mathrm{~m}^{2}$ ) from April 2013 to April 2014. Fish surveys were conducted from November

1222013 to March 2014. During surveys, all individuals (excluding cryptic species) within $2.5 \mathrm{~m}$

123 belts on both sides of the transect lines (total survey area $=250 \mathrm{~m}^{2}$ ) were identified to species

124 level and assigned to size classes $(5-10 \mathrm{~cm}, 10-15 \mathrm{~cm}, 15-20 \mathrm{~cm}, 20-25 \mathrm{~cm}, 25-30 \mathrm{~cm}, 30-35 \mathrm{~cm}$

125 and 35-40 cm). Multiple swims $(\mathrm{n}=3)$ with intervals of $5 \mathrm{~min}$ between swims were conducted

126 on each transect in order to increase the precision of data for each transect. Fish species were

127 categorized into trophic groups according to their dominant food source (herbivores,

128 planktivores, invertebrate feeders and predators) according to descriptions on FishBase (Froese

129 \& Pauly, 2012). Biomass of species and trophic guilds was calculated from abundance, mean

130 length of each size class and species- or family-specific Bayesian length-weight relationship

131 parameters available on FishBase. Shannon's diversity index $(\mathrm{H})$ and Evenness $\left(\mathrm{E}_{\mathrm{H}}\right)$ was 
132 calculated for each survey day from the number and relative contribution of each fish species to

133 total fish abundance counted on all 5 transects.

\section{$134 \quad 2.4$ Monitoring of water parameters}

135 Monitoring of benthic community composition was accompanied by measurements of

136 temperature with a Manta 2 Water Quality Multiprobe deployed directly on the reef substrate

137 (recording over 1-6 hours in 4 min intervals) and weekly determination of inorganic nutrient

138 concentrations. Water samples for nutrient measurements were taken in triplicate from directly

139 above the reef surface within glass jars $(500 \mathrm{~mL})$, filtered immediately through disposable

140 syringe filters (pore size $0.45 \mu \mathrm{m}$ ) and stored cool for transportation. Ammonia $\left(\mathrm{NH}_{4}^{+}\right)$was

141 determined fluorimetrically within $24 \mathrm{~h}$ after sampling with a Trilogy ${ }^{\circledR}$ Laboratory

142 Fluorometer/Photometer (Turner Designs) according to Holmes et al. (1999) and Taylor et al.

143 (2007) (detection limit $(\mathrm{LOD})=0.023 \mu \mathrm{mol} \mathrm{L}-1)$. Determination of phosphate $\left(\mathrm{PO}_{4}{ }^{3-}\right)$ was

144 conducted spectrophotometrically with the same device following the standard protocol of

145 Murphy \& Riley $(1962)(\mathrm{LOD}=0.033 \mu \mathrm{mol} \mathrm{L}-1)$. Sub-samples were kept dark and frozen until

146 the end of the study period and were analyzed for nitrate $\left(\mathrm{NO}_{3}^{-}\right)$and nitrite $\left(\mathrm{NO}_{2}^{-}\right)$concentrations

147 using a Thermo Scientific UV Evolution $201{ }^{\circledR}$ photometer based on a method revised by García-

148 Robledo et al. (2014) $\left(\mathrm{LOD}_{\left(\mathrm{NO}^{-}\right)}=0.151 \mu \mathrm{mol} \mathrm{L}-1 ; \mathrm{LOD}_{(\mathrm{NOx})}=0.162 \mu \mathrm{mol} \mathrm{L}^{-1}\right)$. A detailed

149 description of the temporal variability in physicochemical and organic parameters at the study

150 site can be found in Stuhldreier et al. (in press).

\section{$151 \quad 2.5$ Data analyses}

152 Differences in fish and sea urchin abundances over time were tested with one way ANOVAs

153 followed by Tukey post-hoc tests in SigmaPlot13 for Windows. Correlations between cover

154 types (Pocillopora spp., CCA, C. sertularioides, turf, sand, rubble, cyanobacteria) and between 
155 sea urchin abundances and turf algal cover were tested via Pearson Product Moment Correlation

156 in SigmaPlot 13. Temporal dynamics in environmental parameters and benthic community

157 composition were examined with Principal Coordinate Ordinations (PCO) (Gower, 1966) and

158 tested by Permutation Multivariate Analyses of Variance (PERMANOVA) (Anderson, 2001;

159 Anderson, Gorley \& Clarke, 2008) in PRIMER 6. Prior to analysis, weekly means of

160 environmental parameters (temperature, $\mathrm{PO}_{4}{ }^{3-}, \mathrm{NH}_{4}{ }^{+}, \mathrm{NO}_{3}{ }^{-}$) were normalized and a resemblance

161 matrix calculated using Euclidean similarity. The resemblance matrix of benthic community

162 (cover of Pocillopora spp., dead coral, CCA, turf algae, C. sertularioides, sand, rubble and 163 zoanthids) was calculated using Bray Curtis similarity. The fixed factors used for the analysis

164 were (1) upwelling period with two levels (upwelling: February and March 2014, and non-

165 upwelling: remaining months) and (2) individual months with 13 levels (each month from April

1662013 to April 2014). To test how well patterns in community composition correlated to patterns

167 in environmental parameters, the function RELATE in PRIMER 6 was used, which tests

168 matching of the resemblance matrices by Spearman Rank correlation. Values in the text are

169 reported as mean \pm standard error $(\mathrm{SE})$ if not stated otherwise.

170

\section{Results}

\subsection{Benthic community shifts from turf algae to hard coral dominance}

At Matapalo reef, areas of dead reef structure overgrown with turf algae alternate with healthy

reef areas dominated by live coral cover. At the time of study, the benthic community in healthy reef areas was dominated by the sole reef building corals Pocillopora spp. (P. elegans and $P$. damicornis), crustose coralline algae (CCA) and turf algae. Turf algae communities existed as

177 fine tufts of filamentous algae and cyanobacteria or in denser conglomerates with Dictyota spp. 
178 The green algae Caulerpa sertularioides was the only individually growing fleshy macroalga on

179 the reef and covered large parts of the dead reef framework in shallow areas and on the edges of

180 reef patches. Single coral colonies of Pocillopora spp., Pavona spp. and Psammocora spp. and

181 coral rubble could be found on sandy patches between the reef rock areas. The rugosity of the

182 reef substrate was low with values between 0.08 and 0.16 .

183 Weekly monitoring of permanent quadrats revealed a major shift from turf algae to hard coral

184 dominance within the year of observation (Fig. 2). Cover of the hard coral Pocillopora spp.

185 increased continuously from $22 \%$ in April 2013 to $51 \%$ in April 2014. Turf algae initially

186 covered around $60 \%$ of the substrate, but decreased to $35 \%$ within two weeks in June 2013 . The

187 drop in turf algae cover resulted in an increase in the relative cover of CCA from 15 to $30 \%$, as

188 previously turf algae had overgrown much of the CCA-covered substrate. CCA cover remained

189 around $30 \%$ until January 2014, when it decreased slightly coincident with an increase in coral

190 cover. The macroalga Caulerpa sertularioides initially covered $3 \%$ of the substrate in the

191 permanent quadrats in April 2013, but decreased to $0.1-0.5 \%$ by May 2013. Macroalgae

192 subsequently exhibited temporary increases in cover of up to $5 \%$ in August 2013 and $2.5 \%$ in

193 March 2014. Percent cover of Pocillopora spp. and turf algae in permanent quadrats correlated

194 significantly to their respective coverages in the monthly chain transects covering the whole reef

195 patch (Pearson correlation, $\mathrm{n}=13, r=0.848$ and $0.692, P<0.001$ and $P=0.009$, respectively).

196 By contrast, correlations of CCA and C. sertularioides coverages between the quadrats and chain

197 transects were not significant $(\mathrm{n}=13, r=0.540$ and $0.461, P=0.057$ and 0.113 , respectively),

198 due to the fact that the cover of $C$. sertularioides was higher towards the peripheries of the reef

199 patch. The drop in C. sertularioides cover from April to May 2013 could therefore be observed

200 in a more pronounced way in the chain transects across the whole reef patch (decrease from 15 to 
$2011 \%$ cover, Fig. 4a). The decrease in $C$. sertularioides cover was associated with whitening of the

202 macroalgal's stolons and fronds. Sand and rubble in permanent quadrats increased from around

$2030.5 \%$ substrate cover between April - October 2013 to $1.4 \%$ and 3-4 \% respectively in March

204 and April 2014. Zoanthids were the only sessile invertebrates observed (up to $0.2 \%$ cover).

205 Cover of turf algae in permanent quadrats correlated negatively with that of Pocillopora spp.

206 (Pearson correlation, $r=-0.914)$, CCA $(r=-0.613)$ sand $(r=-0.674)$ and rubble $(r=-0.537$, all $P$

$207<0.001, \mathrm{n}=48)$. Sand and rubble also correlated positively with each other $(r=0.834)$ and with

208 the cover of Pocillopora spp. ( $r=0.818$ and $r=0.756$ respectively, both $P<0.001, \mathrm{n}=48$ ) and

209 cyanobacteria $(r=0.311, P=0.033$ and $r=0.444, P=0.002$ respectively, both $\mathrm{n}=48)$.

210 Multivariate analyses further illustrated the pronounced shift in benthic community composition

211 over the study period (Fig. 3). From April to October 2013 the community shifted along PCO1,

212 which explained $82 \%$ of the total variance in the data and was positively correlated with cover

213 of Pocillopora spp., and negatively with turf algae. From October 2013 to April 2014, the

214 composition shifted further along PCO2, which explained $17.4 \%$ of the total variance and

215 showed a positive correlation to rubble and a negative correlation to CCA. Differences in

216 community composition were significant between months (PERMANOVA, Pseudo- $F(12,34)=$

$21747.848, P($ perm $)=0.001$, perms $=998)$.

$218 \quad 3.2$ Reef exhibits high abundances of herbivorous sea urchins and parrotfish

219 Sea urchin abundances in the reef averaged $5.31 \pm 0.36$ ind. $\mathrm{m}^{-2}$ for Diadema mexicanum and

$2200.16 \pm 0.03$ ind. $\mathrm{m}^{-2}$ for the pencil sea urchin Eucidaris thourasii (Fig. 4b). Individuals of

221 Astropyga pulvinata and Tripneustes depressus occasionally occurred on the reef but were rarely

222 counted during surveys. Abundances of D. mexicanum and E. thourasii did not change

223 significantly during the study period (ANOVA, $F(12,52)=0.991, P=0.470$ and $F(12,52)=$ 
$2241.336, P=0.228$ respectively). Abundances of $D$. mexicanum correlated positively with turf

225 algae cover in permanent quadrats (Pearson correlation, $r=0.787, P=0.001, \mathrm{n}=13$ ) and on

226 benthic transects $(r=0.676, P=0.011, \mathrm{n}=13)$.

227 The Shannon-Wiener diversity of the observed fish community ranged from $\mathrm{H}=1.7$ in March

2282014 to $\mathrm{H}=2.3$ in November 2013 and was positively related to the evenness of species

229 distribution $\left(\mathrm{E}_{\mathrm{H}}=0.59\right.$ to 0.78$)$. Small groupers were the only predators recorded during fish

230 surveys at Matapalo reef. Invertebrate feeders (mainly pufferfish, triggerfish and butterflyfish)

231 dominated total abundance and biomass of fish except in December 2013, when high abundances

232 of planktivorous Chromis atrilobata dominated fish counts, and in March 2014, when many

233 large individuals of the herbivorous parrotfish Scarus ghobban were present (Fig. 4c,d).

234 Herbivores were comprised of territorial damselfish and roving herbivorous parrotfish, while

235 surgeonfish were sometimes observed on the reef during diving, but hardly counted during

236 surveys. Total fish abundance on the reef was significantly elevated in November 2013

237 (ANOVA, $F(4,20)=6.095, P=0.002)$ and total biomass was significantly elevated in November

238 and December 2013 (ANOVA, $F(4,20)=14.729, P<0.001$ ). A statistical correlation of fish

239 abundance or biomass with benthic community composition was not conducted due to the low

240 sample size of fish data $(\mathrm{n}=5)$.

2413.3 Upwelling causes high variability in water temperature and inorganic nutrient

242 concentrations

243 Short drops in temperature of approximately $2{ }^{\circ} \mathrm{C}$ occurred at Matapalo reef in June, October and

244 December 2013. More pronounced and longer lasting cooling events, coupled with increased

245 nutrient concentrations, occurred between February and March 2014 (Fig. 5a,b). Average water

246 temperatures during this upwelling period decreased from $28.5 \pm 0.1{ }^{\circ} \mathrm{C}$ to $26.2 \pm 0.6{ }^{\circ} \mathrm{C}$, while 
247 average $\mathrm{PO}_{4}^{3-}, \mathrm{NH}_{4}{ }^{+}$and $\mathrm{NO}_{3}{ }^{-}$concentrations increased by 70,80 and $270 \%$, respectively.

248 During strongest upwelling events, mean daily seawater temperatures dropped by $7^{\circ} \mathrm{C}$ to

249 minima of $22{ }^{\circ} \mathrm{C}$ and nutrient concentrations increased 5-, 4- and 16-fold to maxima of $1.3 \mu \mathrm{mol}$

$250 \mathrm{PO}_{4}{ }^{3-} \mathrm{L}^{-1}, 2.5 \mu \mathrm{mol} \mathrm{NH}{ }_{4}^{+} \mathrm{L}^{-1}$ and $6.7 \mu \mathrm{mol} \mathrm{NO}_{3}{ }^{-} \mathrm{L}^{-1}$, respectively.

251 According to the PCO analysis, the variability in environmental parameters at Matapalo from

252 April 2013 to April 2014 was mainly explained along PCO1 (79.3\% of total variation), which

253 highly correlated with temperature $(r=-0.86), \mathrm{PO}_{4}^{3-}(r=0.93), \mathrm{NH}_{4}^{+}(r=0.83)$ and $\mathrm{NO}_{3}^{-}(r=$

254 0.95) (Fig. 6). Environmental conditions were significantly different between the upwelling and

255 non-upwelling period $($ PERMANOVA, Pseudo- $F(1,45)=19.87, P($ perm $)=0.001$, perms $=999)$

256 and among individual months (PERMANOVA, Pseudo- $F(12,34)=2.7984, P($ perm $)=0.006$,

257 perms $=997)$. The temporal pattern in environmental parameters did not correlate to the pattern

258 in community composition $(\mathrm{BEST}, \mathrm{Rho}=0.029, P($ perm $)=0.332$, perms $=999)$ and therefore

259 did not explain any variance in the benthic community data.

260

261

\section{Discussion}

262 This is the first study to describe the variability in a benthic coral reef community in response to

263 both an upwelling period and fluctuations in herbivore abundance in a high temporal resolution.

264 The observations demonstrate the dynamic nature of the benthic community at the study site and

265 provide detailed baselines for benthic community composition as well as fish and sea urchin

266 abundances in coral reefs of the eastern tropical Pacific.

267 4.1 Benthic community shift is mainly driven by high coral growth rates

268 An increase in absolute coral cover is important to retain a coral-dominated state in the face of

269 environmental and anthropogenic disturbances, and therefore has been used by many studies to 
270 demonstrate reef recovery (Hughes et al., 2010; Graham, Nash \& Kool, 2011). However, reef

271 recovery cannot be measured based on coral abundance or growth rates alone, and instead

272 requires measures of biodiversity, recruitment rates and colony size distribution - factors that

273 were not assessed in the current study. Nevertheless, the rapid nature of the reef community

274 dynamics observed at the present study site is exceptional. Graham Nash \& Kool (2011)

275 reviewed recovery rates of absolute coral cover in all oceans and found mean annual rates of

$2763.56 \%$ (with a range from 0.13 to $12.49 \%$ ). The annual increase of almost $30 \%$ observed

277 during the present study is among the fastest reported in the scientific literature, exceeded only

278 by an annual live coral cover increase of $>40 \%$ observed in the Great Barrier Reef following a

279

280

281

282

283

284

285

286

287

288

289

290

291

292

coral bleaching event and subsequent bloom of the seaweed Lobophora variegata (Diaz-Pulido et al., 2009). The authors of this study attributed the unusually rapid regrowth of the branching coral Acropora (up to 100 - $200 \%$ within 6 - 12 months) to fast tissue regeneration of small remnants of unbleached live tissue, the high competitive capacity of the corals, and a seasonal dieback in the blooming seaweed. Similarly, the increase in coral cover during the present study did not involve new coral recruitment (no coral recruits were observed on settlement tiles in a parallel study; Roth et al., 2015), but rather was driven by the expansion of remaining live tissue over already existing dead skeleton and high linear growth rates (personal observation and parallel coral growth experiment, unpublished data). Tissue regrowth over already existing coral skeleton seems to offer a rapid mechanism for coral cover increase, likely due to the fact that it does not require new skeletal growth and thereby reduces the energetic costs associated with calcification (Diaz-Pulido et al., 2009). In addition, the linear growth rates for P. damicornis and P. elegans in the Gulf of Papagayo are higher than reported anywhere else in the eastern tropical Pacific (up to $67 \pm 9 \mathrm{~mm} \mathrm{yr}^{-1}$ and $52 \pm 10 \mathrm{~mm} \mathrm{yr}^{-1}$, respectively; Jiménez \& Cortés, 2003) and 
293 appear to be related to high nutrient and food availability during upwelling (Glynn, 1977;

294 Wellington \& Glynn, 1983; D’Croz \& O’Dea, 2007).

\section{4.2 Herbivores likely control algal cover despite seasonal nutrient input}

296 Previous studies in the Gulf of Papagayo reported increased abundances and biomass of

297 Caulerpa sertularioides and Sargassum liebmannii in response to seasonal upwelling

298 (Fernández-García et al., 2012; Cortés, Samper-Villarreal \& Bernecker, 2014), suggesting that

299 the reproductive cycle and benthic coverage of these fleshy macroalgae are primarily controlled

300 by nutrient availability. In a study by Fernández-García et al. (2012) and the current study, $C$.

301 sertularioides cover on the reef decreased rapidly after the macroalgal's stolons and fronds

302 turned white, which is a result of synchronous sexual gamete release. The spawning was likely

303 triggered by changes in environmental conditions after the upwelling peak, when cover and

304 density of the algae had been highest. Despite the pronounced decrease in C. sertularioides after

305 the spawning event in April 2013, macroalgal cover at Matapalo only increased moderately

306 during the following upwelling period in 2014, and therefore did not recover to the full extent of

307 the previous year, despite the high availability of nutrients. The reproductive cycle of $C$.

308 sertularioides may therefore be longer than one calendar year, or alternatively, the upwelling

309 induced elevation in nutrient supply may not have been sustained long enough to induce a

310 renewed macroalgal bloom.

311 Herbivores in coral reef ecosystems have long been recognized to serve as an important top-

312 down control on the establishment and growth of algal communities (e.g. Ogden \& Lobel, 1978;

313 Lewis, 1986; McCook, 1999). In the Caribbean, grazing sea urchins such as Diadema can limit

314 algal cover and thereby play a key role in increasing reef resilience by preventing phase shifts

315 from coral to algal dominance (Lessios, 1988; Knowlton, 1992; Hughes, 1994). Models have 
316 shown that even a moderate sea urchin abundance of 1 ind. $\mathrm{m}^{-2}$ may be sufficient to allow coral

317 population recovery after disturbances (Roff \& Mumby, 2012). The high abundances of

318 Diadema mexicanum (around 5 ind. $\mathrm{m}^{-2}$ ) at our study site suggest they may provide a key control

319 of algal abundance also in the eastern tropical Pacific. We suggest that grazing by sea urchins

320 was especially important in reducing turf algae abundance after a bloom at the beginning of the

321 study period and was therefore responsible for the pronounced decrease in turf algae cover

322 observed in June 2013. Abundances of D. mexicanum were positively correlated with turf algae

323 cover, indicating migration or recruitment patterns of sea urchins according to food availability.

324 By removing turf algae, D. mexicanum uncovered underlying crustose coralline algae and

325 thereby likely facilitated the observed increase in live coral cover. High abundances of Diadema

326 spp. can however also damage a reef by extensively eroding the carbonate substrate (e.g. Ogden,

327 1977; Glynn, 1988; Eakin, 2001). Abundances of sea urchins were above the threshold of 3 ind.

$328 \mathrm{~m}^{-2}$ predicted to shift the reefs in the nearby Culebra Bay from a positive to a negative carbonate

329 balance due to high erosion rates (Alvarado, Cortés \& Reyes-Bonilla, 2012). The reef structure at

330 Matapalo is homogenous and relatively flat, which could facilitate sea urchin erosion and thereby

331 may reduce the structural stability of the carbonate framework.

332 Total reef fish biomass at Matapalo $\left(51 \pm 13 \mathrm{~g} \mathrm{~m}^{-2}\right)$ was comparable to baselines established in

333 the south-western Atlantic (8 - $148 \mathrm{~g} \mathrm{~m}^{-2}$; Bruce et al., 2012), but lower than in the Central

334 Pacific (132 - $527 \mathrm{~g} \mathrm{~m}^{-2}$; Sandin et al., 2008). Herbivorous fish biomass (16 $\left.\pm 5 \mathrm{~g} \mathrm{~m}^{-2}\right)$ was lower

335 than mean values for the Indo-Pacific, but higher than in the Caribbean $\left(29 \pm 4\right.$ and $9 \pm 1 \mathrm{~g} \mathrm{~m}^{-2}$

336 respectively; Roff \& Mumby, 2012). Parrotfish biomass (11.4 $\left.\pm 4.2 \mathrm{~g} \mathrm{~m}^{-2}\right)$ compromised most of

337 the herbivorous fish biomass and was similar to mean values for the Indo-Pacific but much

338 higher than those for the Caribbean $\left(13.1 \pm 2.4\right.$ and $6.7 \pm 0.7 \mathrm{~g} \mathrm{~m}^{-2}$, respectively; Roff \& Mumby, 
339 2012). The low biomass of top predators at Matapalo combined with the dominance of many

340 small lower trophic level consumers could indicate degradation of the studied reef (Sandin et al.,

341 2008). However, the quantification of fish in a relatively small and shallow reef area in the

342 present study excluded large bodied predators and schools of medium sized fish which were

343 present in the deeper and more exposed areas of the bay (personal observation of white tip reef

344 sharks and schools of jacks and trevallies). Accordingly, we observed only one third of total fish

345 species recorded on rocky and deeper study sites in nearby Culebra Bay (Dominici-Arosemena et

346 al., 2005). In the study by Dominici-Arosemena et al. (2005), planktivorous and invertebrate

347 feeding species were more abundant than herbivores, resembling a trophic structure more typical

348 of temperate rather than tropical regions possibly due to the influence of seasonal upwelling. In

349 contrast, the relative abundance of herbivores was high at Matapalo reef (26-51\%), indicating

350 that fish communities in the Gulf of Papagayo differ largely with respect to depth and substrate

351 type.

352 A parallel manipulative study at Matapalo reef showed that herbivorous fish controlled turf and

353 fleshy macroalgal growth on long-term exposed terracotta settlement tiles, even during the

354 nutrient-rich upwelling period (Roth et al., 2015). In contrast, the cover and biomass of turf algae

355 on short-term exposed settlement tiles nearly doubled during upwelling in February and March

3562014 in response to increased nutrient concentrations. This effect was independent of grazing

357 pressure, suggesting nutrient availability plays a role in regulating turf algae settlement (Roth et

358 al., 2015). Due to their high surface to volume ratio, turf algae may take up nutrients from pulse

359 events, such as upwelling, faster than other macroalgae (Carpenter, 1990), and thus episodic

360 nutrient input may particularly support turf algal production and recruitment (Russ \& McCook,

361 1999). Turf algae are able to rapidly overgrow corals, and increased nutrient concentrations can 
362 further exacerbate their competitive superiority (Vermeij et al., 2010; Haas, El-Zibdah \& Wild,

363 2010). In contrast, the present study presents evidence that herbivory can control algae cover in

364 the established reef community, even in times of high nutrient concentrations.

365 Turf algae harbor high abundances of microbes, including potential coral pathogens, and may

366 therefore increase the prevalence of coral diseases and further negatively impact coral health

367 (Sweet, Bythell \& Nugues, 2013; Casey et al., 2014). The prevalence of coral disease at

368 Matapalo was not elevated in months with high turf algal cover (unpublished data). It would

369 however be interesting to assess the microbial diversity at the studied reef, as microbial

370 communities can give insight into the health and degradation status of reef communities

371 (Dinsdale et al., 2008; Bruce et al., 2012).

372 4.4 Local reefs remain sensitive despite their adaptation to upwelling conditions

373 The continuous increase in live coral cover over the studied year suggests that the investigated

374 reef patch was recovering from a disturbance event in the past. However, the increase in coral

375 cover was not apparent for all parts of the $1.2 \mathrm{~km}$ long reef. Furthermore, rapidly increasing coral

376 cover does not always indicate a healthy and resilient reef (Wooldridge, 2014). Repeated coral

377 mortality events over the last decades caused by sedimentation (Jiménez, 2001b), harmful algal

378 blooms (Guzmán et al., 1990) and El Niño warming events (Glynn, 1990; Guzmán \& Cortés,

379 2001; Jiménez et al., 2001) appear to have prevented the coral community at Matapalo from

380 increasing in diversity or developing a more resistant structure. High abundances of sea urchins

381 together with poor cementation of eastern tropical Pacific corals may therefore reduce the

382 stability of local reef frameworks (Cortés, 1997; Manzello et al., 2008; Alvarado et al., 2012).

383 Since maintaining reef framework integrity is equally important as coral growth and recruitment

384 in the recovery process after disturbances (Endean, 1976; Baker, Glynn \& Riegl, 2008), local 
385 reefs in the eastern tropical Pacific will remain sensitive to natural and anthropogenic

386 disturbances, despite high coral growth rates.

387 In conclusion, hard corals and CCA benefited from prevailing environmental conditions during

388 the year of observation, while cover of turf algae and fleshy macroalgae declined. Herbivores

389 likely controlled turf algae growth, thereby facilitating fast coral expansion. In contrast, cover of

390 the macroalga $C$. sertularioides appeared to be controlled by inorganic nutrient availability.

391 Contrary to initial expectations, the benthic community composition did not follow a seasonal

392 cycle corresponding to the non-upwelling and upwelling period, but instead shifted from turf

393 algae to coral dominance over the year of observation. Interannual variability in conditions and

394 community responses are likely high and future studies should address the hypothesis that local

395 reef communities are well adapted to upwelling conditions. The observation that sea urchins

396 largely controlled turf algae cover in the reef should be verified via exclusion experiments.

\section{Acknowledgements:}

We thank I. Gottwald for assistance in the field and the Centro de Investigación en Ciencias del Mar y Limnología (CIMAR), Universidad de Costa Rica, as well as the RIU Guanacaste for logistical support. We also thank the academic editor Fabiano Thompson and an anonymous reviewer for their constructive comments on the manuscript. 
404

405

406

407

408

409

410

411

412

413

414

415

416

417

418

419

420

421

422

423

424

425

426

427

428

429

430

431

432

433

434

435

\section{References}

Alfaro EJ, Cortés J. 2012. Atmospheric forcing of cool subsurface water events in Bahía Culebra, Gulf of Papagayo, Costa Rica. Revista de Biología Tropical 60(Suppl. 2):173-186.

Alfaro EJ, Cortés J, Alvarado JJ, Jiménez C, León A, Sánchez-Noguera C, Nivia-Ruiz J, Ruiz E. 2012. Clima y temperatura sub-superficial del mar en Bahía Culebra, Golfo de Papagayo, Costa Rica. Revista de Biología Tropical 60(Suppl. 2):159-171.

Alvarado JJ, Cortés J, Reyes-Bonilla H. 2012. Reconstruction of Diadema mexicanum bioerosion impact on three Costa Rican Pacific coral reefs. Revista de Biología Tropical 60(Suppl. 2):121-132.

Amador JA, Alfaro EJ, Lizano OG, Magaña VO. 2006. Atmospheric forcing of the eastern tropical Pacific: A review. Progress in Oceanography 69:101-142.

Anderson MJ. 2001. A new method for non-parametric multivariate analysis of variance. Austral Ecology 26:32-46.

Anderson MJ, Gorley RN, Clarke KR. 2008. PERMANOVA+ for PRIMER: Guide to Software and Statistical Methods. pp. 214.

Baker AC, Glynn PW, Riegl B. 2008. Climate change and coral reef bleaching: An ecological assessment of long-term impacts, recovery trends and future outlook. Estuarine, Coastal and Shelf Science 80:435-471.

Bruce T, Meirelles PM, Garcia G, Paranhos R, Rezende CE, de Moura RL, Filho RF, Coni EOC, Vasconcelos AT, Filho G, Hatay M, Schmieder R, Edwards R, Dinsdale E, Thompson FL. 2012. Abrolhos bank reef health evaluated by means of water quality, microbial diversity, benthic cover, and fish biomass data. PLOS ONE 7:e36687.

Carpenter RC. 1990. Competition among marine macroalgae: A physiological perspective. Journal of Phycology 26:6-12.

Casey JM, Ainsworth TD, Choat JH, Connolly SR. 2014. Farming behaviour of reef fishes increases the prevalence of coral disease associated microbes and black band disease. Proceedings of the Royal Society B 281:20141032.

Cortés J. 1997. Biology and geology of eastern Pacific coral reefs. Coral Reefs 16(Suppl.):S39S46.

Cortés J, Samper-Villarreal J, Bernecker A. 2014. Seasonal phenology of Sargassum liebmannii J. Agardh (Fucales, Heterokontophyta) in an upwelling area of the Eastern Tropical Pacific. Aquatic Botany 119:105-110. 
436

D’Croz L, O’Dea A. 2007. Variability in upwelling along the Pacific shelf of Panama and implications for the distribution of nutrients and chlorophyll. Estuarine, Coastal and Shelf Science 73:325-340.

Diaz-Pulido G, McCook LJ, Dove S, Berkelmans R, Roff G, Kline DI, Weeks S, Evans RD, Williamson DH, Hoegh-Guldberg O. 2009. Doom and boom on a resilient reef: climate change, algal overgrowth and coral recovery. PLOS ONE 4:e5239.

Dinsdale EA, Pantos O, Smriga S, Edwards RA, Angly F, Wegley L, Hatay M, Hall D, Brown E, Haynes M, Krause L, Sala E, Sandin SA, Thurber RV, Willis BL, Azam F, Knowlton N, Rohwer F. 2008. Microbial ecology of four coral atolls in the Northern Line Islands. PLOS ONE 3:e1584.

Done T. 1992. Phase shifts in coral reef communities and their ecological significance. Hydrobiologia 247:121-132.

Dominici-Arosemena A, Brugnoli-Olivera E, Cortés-Núñez J, Molina-Ureña H, Quesada-Alpizar M. 2005. Community structure of eastern Pacific reef fishes (Gulf of Papagayo, Costa Rica). Tecnosciencia 7:19-41.

Eakin CM. 2001. A tale of two ENSO events: Carbonate budgets and the influence of two warming disturbances and intervening variability, Uva Island, Panama. Bulletin of Marine Science 69:171-186.

Eidens C, Hauffe T, Bayraktarov E, Wild C, Wilke T. 2015. Multi-scale processes drive benthic community structure in upwelling-affected coral reefs. Frontiers in Marine Science 2:1-11.

Endean R. 1976. Destruction and recovery of coral reef communities. In: Biology and Geology of Coral Reefs. Vol. 3. 215-254.

Fernández-García C, Cortés J, Alvarado JJ, Nivia-Ruiz J. 2012. Physical factors contributing to the benthic dominance of the alga Caulerpa sertularioides (Caulerpaceae, Chlorophyta) in the upwelling Bahía Culebra, north Pacific of Costa Rica. Revista de Biología Tropical 60(Suppl. 2):93-107.

Fiedler PC, Talley LD. 2006. Hydrography of the eastern tropical Pacific: A review. Progress in Oceanography 69:143-180.

Froese R, Pauly D. 2012. FishBase, available at www.fishbase.org

García-Robledo E, Corzo A, Papaspyrou S. 2014. A fast and direct spectrophotometric method for the sequential determination of nitrate and nitrite at low concentrations in small volumes. Marine Chemistry 162:30-36.

Glynn PW. 1977. Coral growth in upwelling and nonupwelling areas off the Pacific coast of Panama. Journal of Marine Research 35:567-585. 
470

Glynn PW. 1988. El Niño warming, coral mortality and reef framework destruction by echinoid bioerosion in the eastern Pacific. Galaxea 7:129-160.

Glynn PW. 1990. Coral mortality and disturbance to coral reefs in the tropical eastern Pacific. In Glynn PW, ed. Global Ecological Consequences of the 1982-83 El Niño-Southern Oscillation. Amsterdam: Elsevier. 55-126.

Glynn PW, Stewart RH. 1973. Distribution of coral reefs in the Pearl Islands (Gulf of Panamá) in relation to thermal conditions. Limnology and Oceanography 18:367-379.

Glynn PW, D’Croz L. 1990. Experimental evidence for high temperature stress as the cause of El Niño-coincident coral mortality. Coral Reefs 8:181-191.

Gove JM, Williams GJ, McManus MA, Clark SJ, Ehses JS, Wedding L. 2015. Coral reef benthic regimes exhibit non-linear threshold responses to natural physical drivers. Marine Ecology Progress Series 522:33-48.

Gower J. 1966. Some distance properties of latent root and vector methods used in multivariate analysis. Biometrika 53:325-338.

Graham NAJ, Nash KL, Kool JT. 2011. Coral reef recovery dynamics in a changing world. Coral Reefs 30:283-294.

Guzmán HM, Cortés J. 2001. Changes in reef community structure after fifteen years of natural disturbances in the eastern Pacific (Costa Rica). Bulletin of Marine Science 69:133-149.

Guzmán HM, Cortés J, Glynn PW, Richmond RH. 1990. Coral mortality associated with dinoflagellate blooms in the eastern Pacific (Costa Rica and Panama). Marine Ecology Progress Series 60:299-303.

Haas AF, El-Zibdah M, Wild C. 2010. Seasonal monitoring of coral-algae interactions in fringing reefs of the Gulf of Aqaba, Northern Red Sea. Coral Reefs 29:93-103.

Holmes RM, Aminot A, Kérouel R, Hooker BA, Peterson BJ. 1999. A simple and precise method for measuring ammonium in marine and freshwater ecosystems. Canadian Journal of Fisheries and Aquatic Sciences 56:1801-1808.

Hughes TP. 1994. Catastrophes, phase shifts, and large-scale degradation of a Caribbean coral reef. Science 265:1547-1551.

Hughes TP, Graham NAJ, Jackson JBC, Steneck RS. 2010. Rising to the challenge of sustaining coral reef resilience. Trends in Ecology and Evolution 25:633-642.

Hughes TP, Baird AH, Dinsdale EA, Moltschaniwskyj NA, Pratchett MS, Tanner JE, Willis BL. 2012. Assembly rules of reef corals are flexible along a steep climatic gradient. Current Biology 22:736-741. 
503

Jiménez C. 2001a. Seawater temperature measured at the surface and at two depths (7 and $12 \mathrm{~m}$ ) in one coral reef at Culebra Bay, Gulf of Papagayo, Costa Rica. Revista de Biología Tropical 49(Suppl. 2):153-161.

Jiménez C. 2001b. Arrecifes y ambientes coralinos de Bahía Culebra, Pacífico de Costa Rica: aspectos biológicos, económico-recreativos y de manejo. Revista de Biología Tropical 49(Suppl. 2):215-231.

Jiménez C, Cortés J, León A, Ruíz E. 2001. Coral bleaching and mortality associated with the 1997-1998 El Niño in an upwelling environment in the eastern Pacific (Gulf of Papagayo, Costa Rica). Bulletin of Marine Science 69:151-169.

Jiménez C, Cortés J. 2003. Growth of seven species of scleractinian corals in an upwelling environment of the eastern Pacific (Golfo de Papagayo, Costa Rica). Bulletin of Marine Science 72:187-198.

Kleypas JA, McManus JW, Meñez LAB. 1999. Environmental limits to coral reef development: Where do we draw the line? American Zoologist 39:146-159.

Knowlton N. 1992. Thresholds and multiple stable states in coral reef community dynamics. American Zoologist 32:674-682.

Leichter JJ, Miller SL. 1999. Predicting high-frequency upwelling: Spatial and temporal patterns of temperature anomalies on a Florida coral reef. Continental Shelf Research 19:911-928.

Leichter JJ, Stewart HL, Miller SL. 2003. Episodic nutrient transport to Florida coral reefs. Limnology and Oceanography 48:1394-1407.

Leichter JJ, Deane GB, Stokes MD. 2005. Spatial and temporal variability of internal wave forcing on a coral reef. Journal of Physical Oceanography 35:1945-1962.

Lessios HA. 1988. Mass mortality of Diadema antillarum in the Caribbean: What have we learned? Annual Review of Ecology and Systematics 19:371-393.

Lewis SM. 1986. The role of herbivorous fishes in the organization of a Caribbean Reef Community. Ecological Monographs 56:183-200.

Littler MM, Littler DS. 1984. Relationships between macroalgal funcional form groups and substrata stability in a subtropical rocky-intertidal system. Journal of Experimental Marine Biology and Ecology 74:13-34.

Manzello DP, Kleypas JA, Budd DA, Eakin CM, Glynn PW, Langdon C. 2008. Poorly cemented coral reefs of the eastern tropical Pacific: possible insights into reef development in a high$\mathrm{CO}_{2}$ world. Proceedings of the National Academy of Sciences of the United States of America 105:10450-10455. 
536

McCook LJ. 1999. Macroalgae, nutrients and phase shifts on coral reefs: scientific issues and management consequences for the Great Barrier Reef. Coral Reefs 18:357-367.

McCreary JP, Lee HS, Enfield DB. 1989. The response of the coastal ocean to strong offshore winds: With application to circulations in the Gulfs of Tehuantepec and Papagayo. Journal of Marine Research 47:81-109.

Murphy J, Riley JP. 1962. A modified single solution method for the determination of phosphate in natural waters. Analytica Chimica Acta 27:31-36.

Ogden JC. 1977. Carbonate-sediment production by parrot fish and sea urchins on Caribbean reefs. Studies in Geology 4:281-288.

Ogden JC, Lobel PS. 1978. The role of herbivorous fishes and urchins in coral reef communities. Environmental Biology of Fishes 3:49-63.

Rixen T, Jiménez C, Cortés J. 2012. Impact of upwelling events on the sea water carbonate chemistry and dissolved oxygen concentration in the Gulf of Papagayo (Culebra Bay), Costa Rica: Implications for coral reefs. Revista de Biología Tropical 60(Suppl. 2):187195.

Roder C, Jantzen C, Schmidt GM, Kattner G, Phongsuwan N, Richter C. 2011. Metabolic plasticity of the corals Porites lutea and Diploastrea heliopora exposed to large amplitude internal waves. Coral Reefs 30:57-69.

Roff G, Mumby PJ. 2012. Global disparity in the resilience of coral reefs. Trends in Ecology and Evolution 27:404-413.

Roth F, Stuhldreier I, Sánchez-Noguera C, Morales-Ramírez Á, Wild C. 2015. Effects of simulated overfishing on the succession of benthic algae and invertebrates in an upwellinginfluenced coral reef of Pacific Costa Rica. Journal of Experimental Marine Biology and Ecology 468:55-66.

Russ GR, McCook LJ. 1999. Potential effects of a cyclone on benthic algal production and yield to grazers on coral reefs across the central Great Barrier Reef. Journal of Experimental Marine Biology and Ecology 235:237-254.

Sandin SA, Smith JE, Demartini EE, Dinsdale EA, Donner SD, Friedlander AM, Konotchick T, Malay M, Maragos JE, Obura D, Pantos O, Paulay G, Richie M, Rohwer F, Schroeder RE, Walsh S, Jackson JBC, Knowlton N, Sala E. 2008. Baselines and degradation of coral reefs in the Northern Line Islands. PLOS ONE 3:e1548.

Schmidt GM, Phongsuwan N, Jantzen C, Roder C, Khokiattiwong S, Richter C. 2012.Coral community composition and reef development at the Similan Islands, Andaman Sea, in response to strong environmental variations. Marine Ecology Progress Series 456:113-126. 
570

571

572

573

574

575

576

577

578

579

580

581

582

583

584

585

586

587

588

589
Stuhldreier I, Sánchez-Noguera C, Rixen T, Cortés J, Morales A, Wild C. (in press). Effects of seasonal upwelling on inorganic and organic matter dynamics in the water column of eastern Pacific coral reefs. PLOS ONE.

Sweet MJ, Bythell JC, Nugues MM. 2013. Algae as reservoirs for coral pathogens. PLOS ONE 8:e69717.

Taylor BW, Keep CF, Hall Jr RO, Koch BJ, Tronstad LM, Flecker AS, Ulseth AJ. 2007. Improving the fluorometric ammonium method: matrix effects, background fluorescence, and standard additions. Journal of the North American Benthological Society 26:167-177.

Vermeij MJA, van Moorselaar I, Engelhard S, Hörnlein C, Vonk SM, Visser PM. 2010. The effects of nutrient enrichment and herbivore abundance on the ability of turf algae to overgrow coral in the Caribbean. PLOS ONE 5:1-8.

Wellington GM, Glynn PW. 1983. Environmental influences on skeletal banding in eastern Pacific (Panama) corals. Coral Reefs 1:215-222.

Willett CS, Leben RR, Lavín MF. 2006. Eddies and Tropical Instability Waves in the eastern tropical Pacific: A review. Progress in Oceanography 69:218-238.

Williams GJ, Gove JM, Eynaud Y, Zgliczynski BJ, Sandin SA. 2015. Local human impacts decouple natural biophysical relationships on Pacific coral reefs. Ecography 38:1-11.

Wooldridge SA. 2014. Assessing coral health and resilience in a warming ocean: why looks can be deceptive. Bioessays 36:1041-1049. 
1

Location of the Gulf of Papagayo (a) and Matapalo reef (b).

The photograph was taken at the study site indicated in (b) at $5 \mathrm{~m}$ water depth (mwd) and shows the reef structure and dominant benthic organisms.
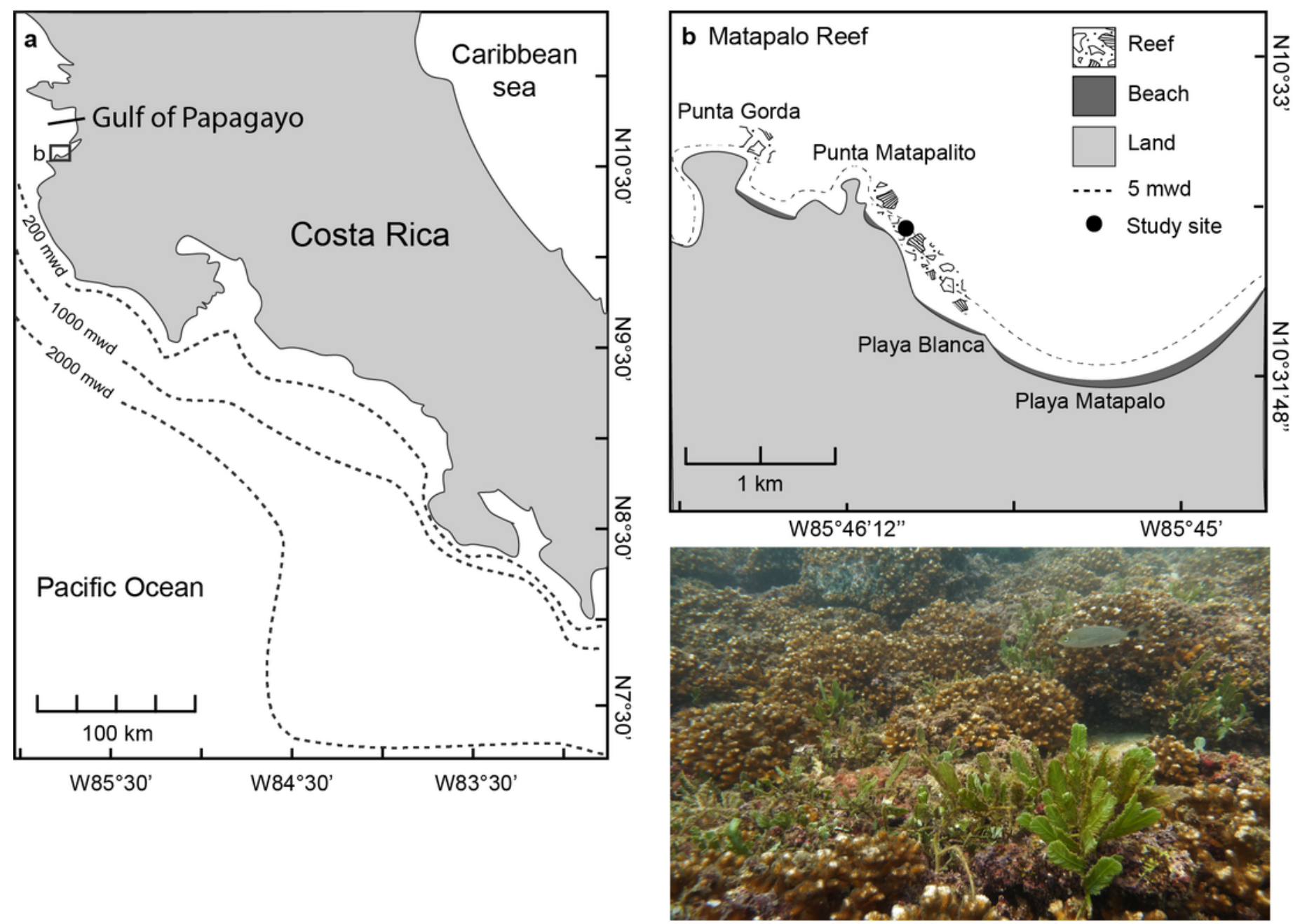
2

Temporal changes in coral reef community composition.

Displayed is the mean proportional cover of benthic organisms or substrates in permanent quadrats of $50 \times 50 \mathrm{~cm}(\mathrm{n}=5)$ from April 2013 to April 2014 in a weekly resolution. Shading indicates the period of strongest upwelling in February and March (see Fig. 4).

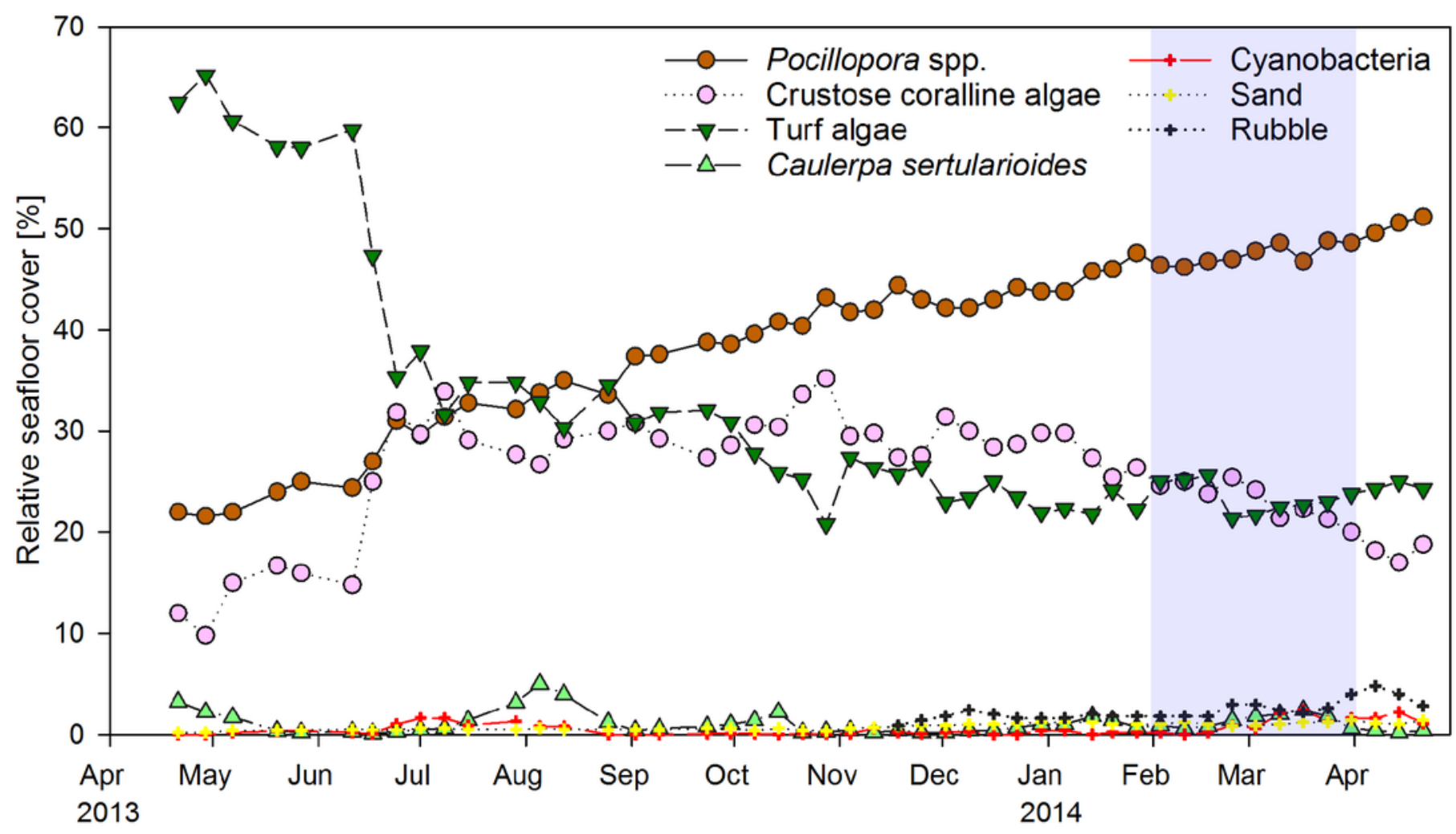


3

Temporal shift in benthic community composition.

Weekly sampling data from April 2013 to April 2014 were grouped by the factor month. The distance between data points reflects their similarity in benthic community composition (close $=$ similar) and the shift along axes can be assigned to changes in benthic cover types (arrows). PCO1 correlates positively to cover of Pocillopora spp. (Pocillopora) (Pearson correlation, $r=0.94)$, sand $(r=0.70)$, rubble $(r=0.57)$ and crustose coralline algae (CCA) $(r=0.57)$ and negatively to turf algae (Turf) $(r=-0.99)$. PCO2 correlates positively to rubble $(r=0.71)$ and sand $(r=0.51)$ and negatively to CCA $(r=-0.81)$ and zoanthids $(r=-0.75)$. Only variables with $r>0.5$ are displayed.

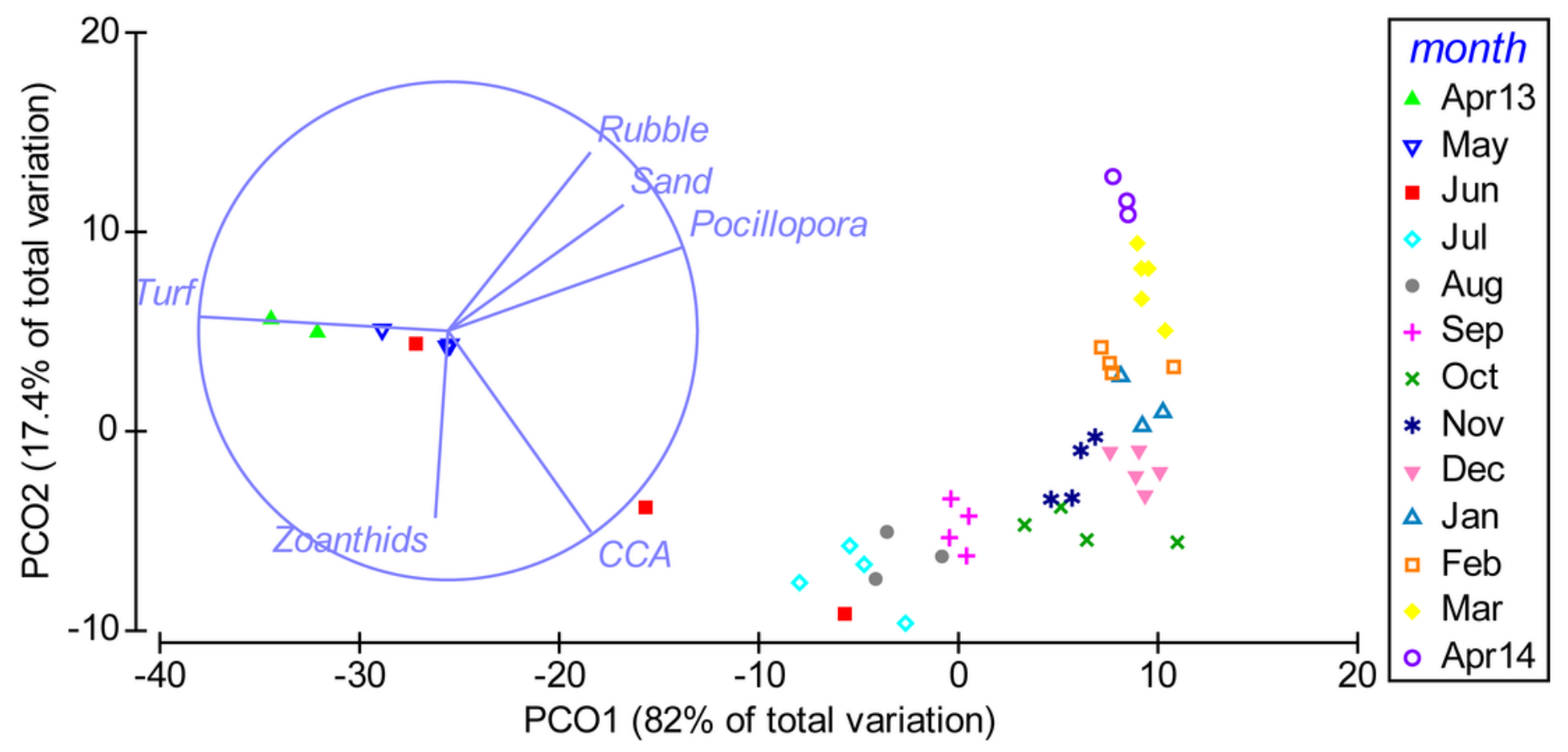


4

Changes in sea urchin and fish community.

Displayed are mean \pm SE abundances of (a) sea urchins and (b) fish, (c) fish biomass

calculated from abundances and mid length of size classes and (d) relative abundance of parrotfish size classes (in $\mathrm{cm}$ ) in permanent belt transects $(\mathrm{n}=5)$ from April 2013 to April 2014 in a monthly resolution.

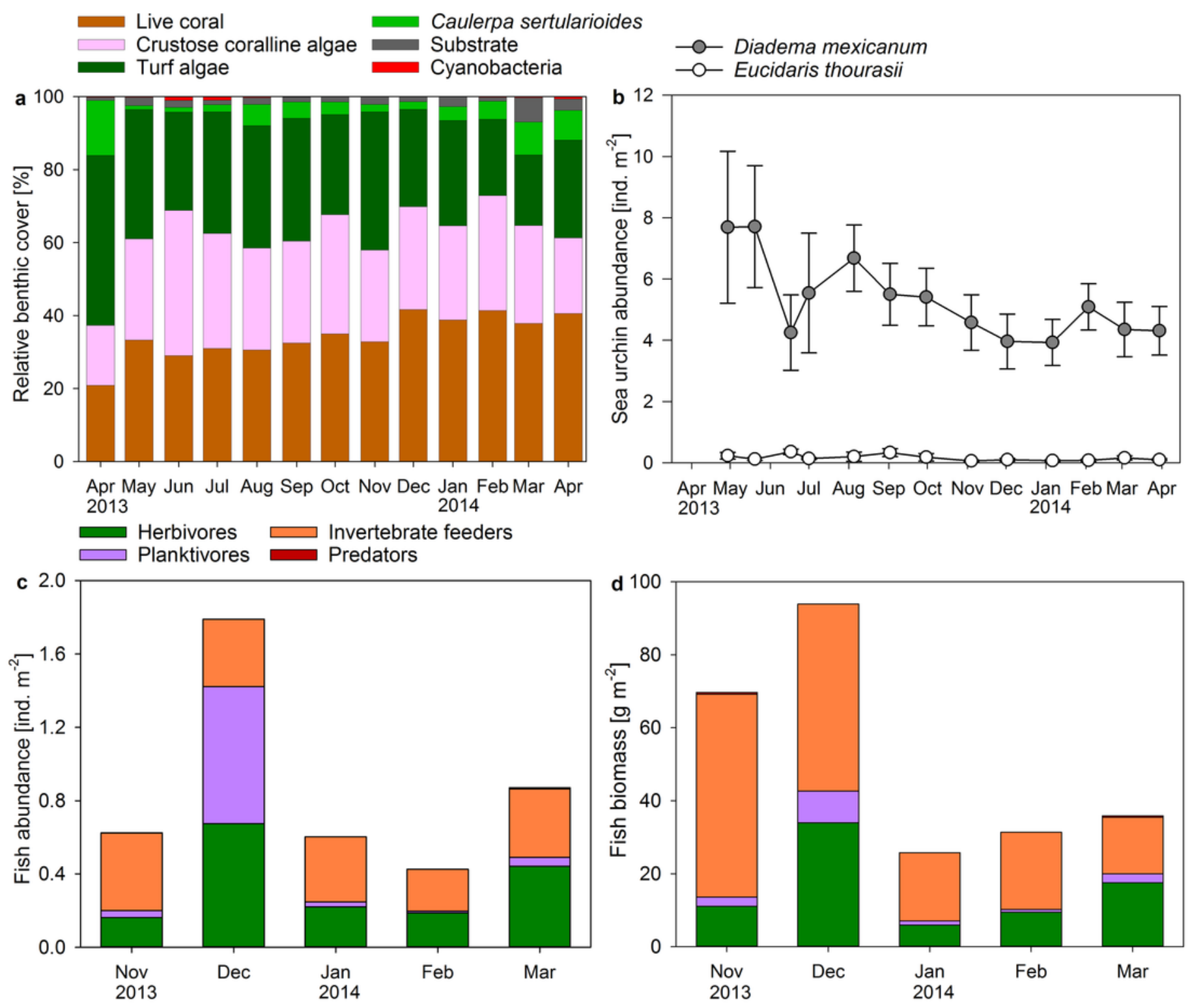




\section{5}

Changes in temperature and nutrient concentrations.

Displayed are mean \pm SE values for (a) water temperature (measured over 1-6 $\mathrm{h}$ in 4 min intervals) and (b) nutrient concentrations $(n=3)$ directly above the reef substrate from April 2013 to April 2014 in a weekly resolution. Shading indicates period of strongest upwelling in February and March.
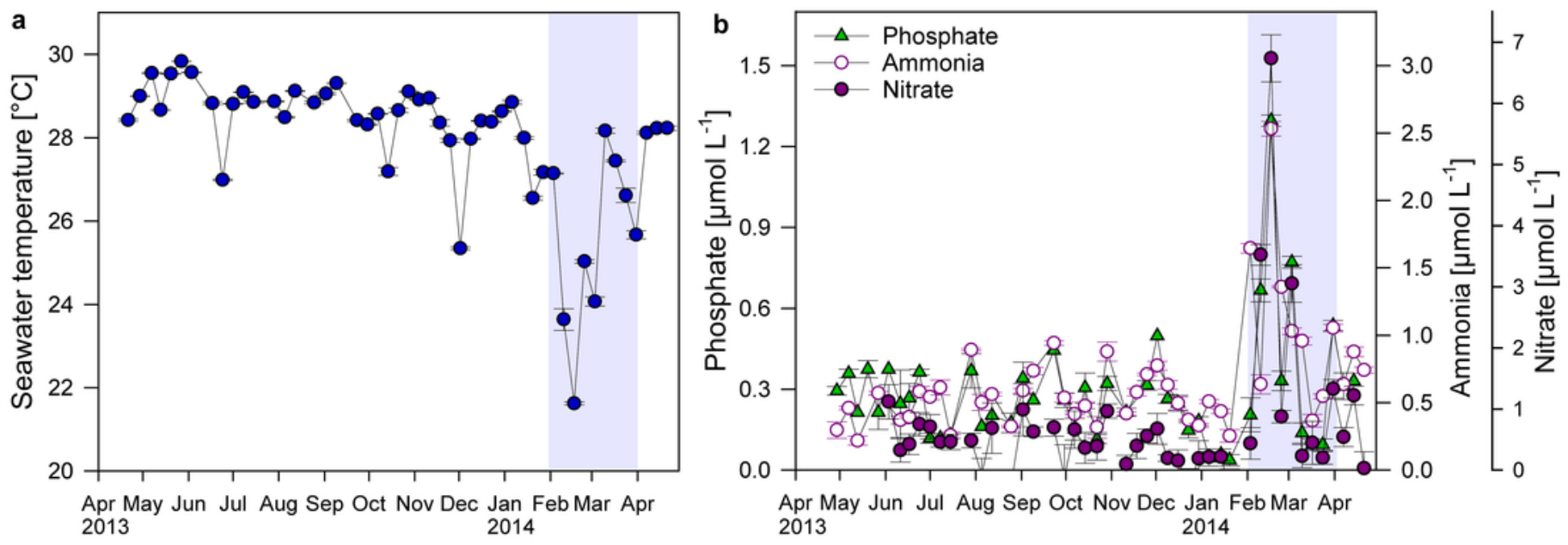
6

Temporal pattern in environmental parameters.

Weekly sampling data from April 2013 to April 2014 were grouped by the factor upwelling period. The distance between data points reflects their similarity in environmental conditions (close $=$ similar) and the separation along axes can be assigned to changes in environmental parameters (arrows). Sampling points in upwelling season are separated from the rest along PCO1, correlating highly with temperature $(r=-0.86)$, phosphate (PO4) $(r=0.93)$, ammonia $(\mathrm{NH} 4)(r=0.83)$ and nitrate $(\mathrm{NO} 3)(r=0.95)$.

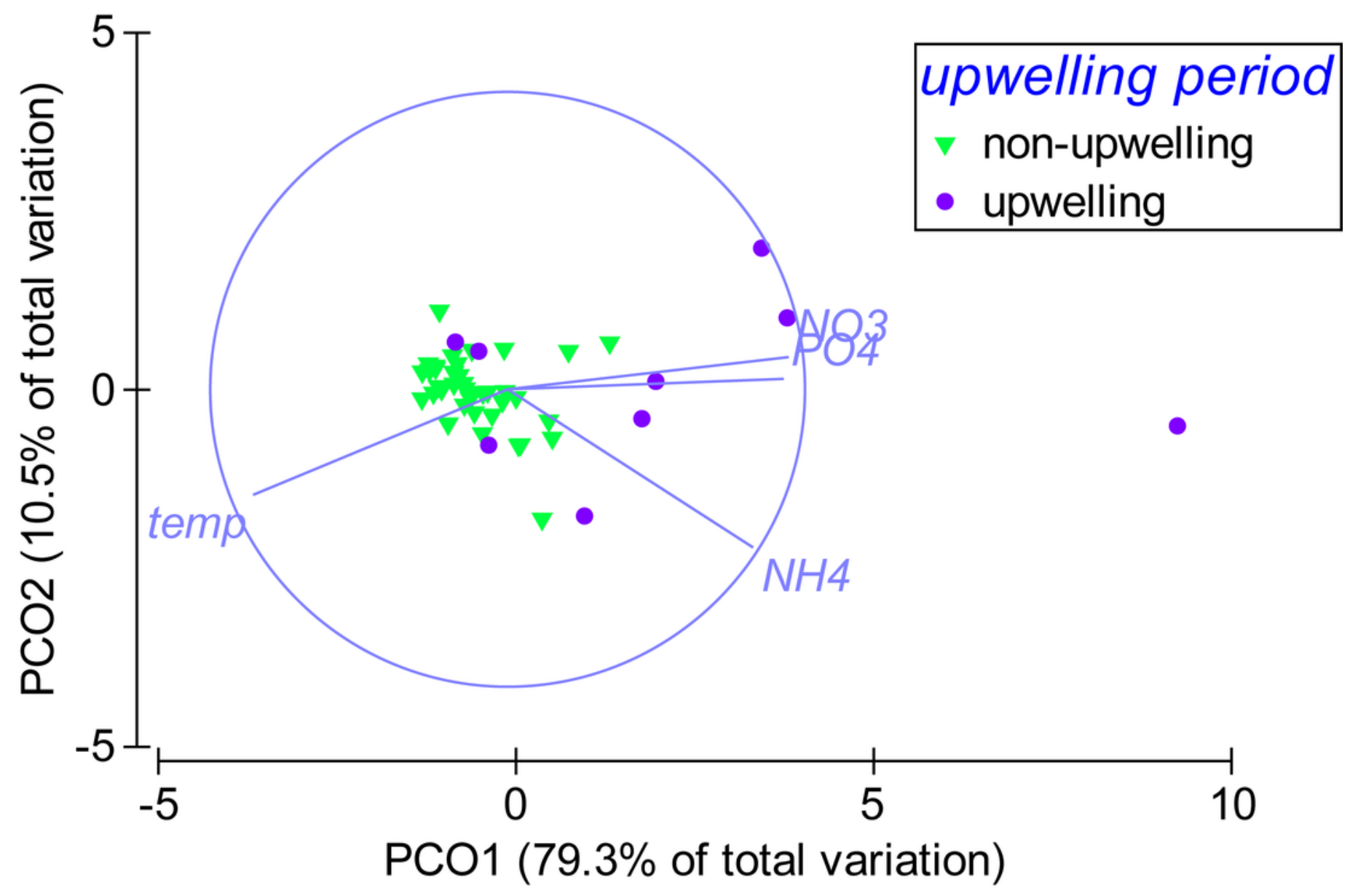

